\title{
Universal Health Coverage and COVID-19 Pandemic: A Bangladesh Perspective
}

\author{
Most. Zannatul Ferdous ${ }^{1 *}$, Ummay Soumayia Islam ${ }^{1}$
}

Most. Zannatul Ferdous

Jahangirnagar University

Email: m.zannatul.ferdous@ juniv.edu

Ummay Soumayia Islam

Jahangirnagar University

Email: sumaiyaaislam@gmail.com

${ }^{1}$ Department of Public Health and Informatics, Jahangirnagar University, Savar, Dhaka-1342

\section{Corresponding author}

* Most. Zannatul Ferdous

Lecturer

Department of Public Health and Informatics

Jahangirnaagar University

Savar, Dhaka-1342

$+8801768894096$

\section{Authors Contributions}

Most. Zannatul Ferdous: Conceptualization, Writing-original draft, Editing, and Validation; Ummay Soumayia Islam: Writing-original draft, Editing, and Validation. 
medRxiv preprint doi: https://doi.org/10.1101/2020.11.11.20229526; this version posted November 13,2020 . The copyright holder for this preprint (which was not certified by peer review) is the author/funder, who has granted medRxiv a license to display the preprint in It is made available under a CC-BY-NC-ND 4.0 International license.

\begin{abstract}
Background: Like many other countries around the world, Bangladesh adopts Universal Health Coverage (UHC) as a national aspiration. The central theme of its providing quality and affordable health services which is a significant element of social protection. This paper was aimed to provide a narrative understanding of the perspectives of UHC in Bangladesh towards COVID-19 based on the existing literature.
\end{abstract}

Methods: We conducted a review combining articles and abstracts with full HTML and PDF format. We searched Google Scholar, ScienceDirect and Google using multiple terms related to UHC, COVID-19 and Bangladesh without any date boundary and without any basis of types of studies, that is, all types of studies were scrutinized.

Results: This short description highlights that the current pandemic COVID-19 holds lessons that health systems and economies in several countries like Bangladesh are not in enough preparation to tackle a massive public health crisis. It reports the shortage of health workers, scarcity of personal protective equipment, limited and ineffective diagnostic facilities, inadequate infrastructure of health care facilities, scarcity of drugs, and underfunded health services. Further, COVID-19 pandemic highlights the country's health system needs an ongoing rehab post-COVID-19 with strong coordination in governance, in health economics, in health systems, in information systems, as well as in community participation in health to achieve UHC.

Conclusions: Addressing the needs for UHC achievement, it is important to break down the access barriers and keeping up to date all the activities addressing public health crisis like COVID-19.

\title{
Perspectives
}

World Health Organization (WHO) defines Universal Health Coverage (UHC) as- ensuring access to needed health care services including health promotion, prevention, treatment, and 
medRxiv preprint doi: https://doi.org/10.1101/2020.11.11.20229526; this version posted November 13,2020 . The copyright holder for this preprint (which was not certified by peer review) is the author/funder, who has granted medRxiv a license to display the preprint in It is made available under a CC-BY-NC-ND 4.0 International license .

rehabilitation when and where appropriate without financial hardship among the user (WHO, 2020a).Approximately half of the people across the globe are deprived from health services they need including 100 million are pushed below poverty line every year because of out of pocket payment on their health[1]. In 2015, the nations of the world set UHC as one of the target under goal 3 when adopting Sustainable Development Goals. By achieving UHC countries can achieve progress towards other health-related targets including other goals since sound health allows children to learn, adults to earn, helps to reduce poverty, and strengthen economic development[2].Therefore, all countries has given their consent towards achieving UHC as part of the 2030 Agenda except Bangladesh. According to the commitment of the Prime Minister of Bangladesh in the $64^{\text {th }}$ World Health Assembly held in May 2011, the country committed to gain UHC by 2032 [3]. Less than $1 \%$ of the total population has a health coverage scheme against health expenditure including $3.8 \%$ is pushed into poverty line for paying health services each year. Though Bangladesh has achieved significant progress over the last 2 decades, $64 \%$ health expenditure is still come from out of pocket. As a result it is experiencing the highest expenditure (15\%) compared to neighboring country India (10\% to $12 \%)$ and Thailand (2\%)[4].

The recent COVID-19 is an ongoing global public health crisis according to WHO declaration on $30^{\text {th }}$ January, 2020 which was first emerged at Wuhan city of China[5], [6]. In Bangladesh, Institute of Epidemiology, Disease Control and Research (IEDCR) declared the first confirmed cases on $8^{\text {th }}$ March, 2020 [7]. After that country has taken numerous control measures fighting against COVID-19 though these available control measures are significantly influenced by the knowledge, attitudes, and practices (KAP) towards COVID19[8]. However, adoption of control measures, the country is facing frequent problem like economic and social standstill and among them health sector is the most affected sector by the pandemic[9]. As of $9^{\text {th }}$ November, 2020 Bangladesh confirmed 42,238 cases with 6067 
medRxiv preprint doi: https://doi.org/10.1101/2020.11.11.20229526; this version posted November 13, 2020. The copyright holder for this preprint (which was not certified by peer review) is the author/funder, who has granted medRxiv a license to display the preprint in It is made available under a CC-BY-NC-ND 4.0 International license .

deaths and 338,145 recovery [10]. This study aims to assess the impact of COVID-19 in Bangladesh and lesson learned towards achieving UHC by 2032 .

\section{Literature search strategies}

We reviewed the literature (PubMed, Google Scholar, ScienceDirect, Google and online newspapers in Bangladesh) to get recent information on UHC, UHC and COVID-19 in Bangladesh.

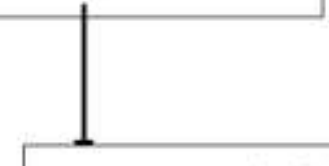

27 Records after duplicates removed

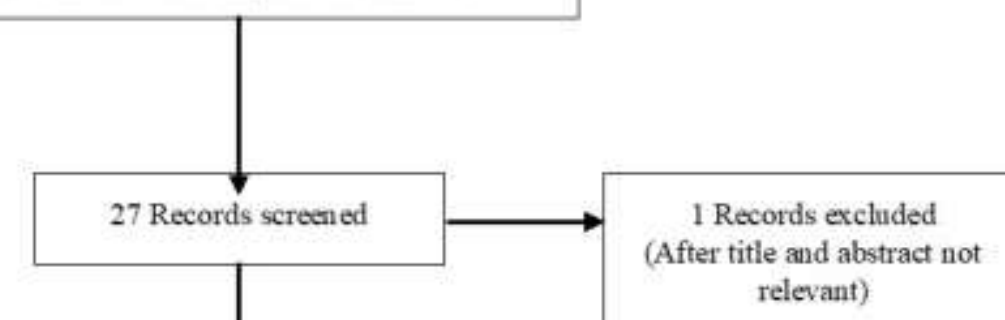

26 Full-text articles assessed for eligibility

3 Full-text articles excluded. with reasons

Figure 1: Flow diagram of the study selection process (PRISMA flow diagram) 
medRxiv preprint doi: https://doi.org/10.1101/2020.11.11.20229526; this version posted November 13,2020 . The copyright holder for this preprint (which was not certified by peer review) is the author/funder, who has granted medRxiv a license to display the preprint in It is made available under a CC-BY-NC-ND 4.0 International license .

\section{Lessons towards COVID-19 and Bangladesh}

Public health emergency leads any country in a danger if it beyond under control. Likewise, recently declared public health emergency COVID-19 affected more than 216 countries and territories with $50,782,732$ confirmed cases and $1,262,751$ deaths as of $9^{\text {th }}$ November, 2020 around the world. It has shown the critical need for the preparedness during a disaster to the world. Preparation is the fundamental tool for mitigating the impact of any catastrophe and COVID-19 taught the world a great lesson by showing its severity. When many countries are struggling to provide UHC to its community, a new emerging public health problem such as COVID-19 pose a global threat and continue to rise and spread its impact on people in many ways like physically, mentally, economically, and so on. Extended health emergencies due to the pandemic of COVID-19 the supply sides (like health systems) went under an enormous pressure. The aftermath has a significant impact on the vulnerable population by lacking social protection and access to health care services in their normal life [11]. The Lancet Global Health Commission addressed poor quality care is now a bigger barrier to reducing mortality than insufficient access. It estimates approximately $60 \%$ of deaths from conditions amenable to health care are due to poor quality care, whereas the remaining deaths result from non-utilization of the health system[12]. This situation more is dreadful for vulnerable groups including the poor, the less educated, adolescents, those with stigmatized conditions, and those at the edges of health systems, such as people in prison [13]. Compared to other South Asian countries, Bangladesh has one of the best government health infrastructure including 500 upazila health complex, 5000 union sub centers, 13000 satellite clinics, secondary, and tertiary care hospitals. Yet the country is facing lack of skilled health care professionals particularly in rural areas, scarcity of health care resources, financial constraints. Most of the time patients have to pay all cost related to health service from their pocket which leads to poor people become poorer and even rich are also facing hardship with 
medRxiv preprint doi: https://doi.org/10.1101/2020.11.11.20229526; this version posted November 13,2020 . The copyright holder for this preprint (which was not certified by peer review) is the author/funder, who has granted medRxiv a license to display the preprint in It is made available under a CC-BY-NC-ND 4.0 International license.

the costly treatment procedure[4]. During COVID-19 pandemic the country has a severe scarcity of testing kits in stocks and only some 20,000 have been distributed to other parts testing laboratories around the country[14], [15]. However, China provide some testing kits, masks, infrared thermometers, and PPE to deal with the crisis but this amount only covers a small proportion needs[16].

Approximately, 1.1 million slum dwellers living in extremely close quarters are hardly conscious about the threat of COVID-19 and most of them passed their life with great difficulty by losing jobs due to pandemic crisis. These families have less facilities of bathroom, toilet with scarcity of water. Therefore, maintaining hygiene is a challenge to them. The same situation goes for Rohingya refugees, who fled in Bangladesh from neighboring country Myanmar in 2017, leading to vulnerable health condition among these population and increase more chance to illness[17-19]. Since there is scarcity of PPE (personal protective equipment), testing facilities most of the health workers which is not sufficient compared to large population refused to provide service with this crisis due to fear of infection[20]. According to a study conducted in Gazipur Upazila, e-health care have dropped $80 \%$ due to absence of doctors, $58 \%$ being deprived of basic human needs, $71 \%$ pregnant women missed their regular ANC check-ups, $70 \%$ female faced familial complications, and Expanded Program on Immunization (EPI) has also dropped during pandemic [21]. As a result, shortage of health workers, scarcity of personal protective equipment, inadequate infrastructure of health care facilities, scarcity of drugs, and underfunded health services has revealed more clearly during this pandemic that shows a consistent impediment to achieve UHC in Bangladesh. In addition relocating medical staff to emergency site from previous department increase scarcity of service delivery in those site like non-communicable diseases, HIV, Tuberculosis, mental health, maternal and child health, increased unwanted pregnancy, malaria, and diphtheria[9]. Furthermore, in this 
medRxiv preprint doi: https://doi.org/10.1101/2020.11.11.20229526; this version posted November 13,2020 . The copyright holder for this preprint (which was not certified by peer review) is the author/funder, who has granted medRxiv a license to display the preprint in It is made available under a CC-BY-NC-ND 4.0 International license.

critical time, smart planning with sufficient preparation for mitigating the incidence and prevalence of disease including designing the future prospect is very important to achieve UHC[22]. Because evidence on the management approaches of current COVID-19 pandemic is still limited though the numbers of affected countries are increasing as the days go by[23].

However, to achieve UHC in Bangladesh should include development of a long term national human resources policy and action plan considering the emerging and re-emerging health risks, establishment of a national insurance system, building of an interoperable electronic health information system and investment to strengthen the capacity of the ministry of health.

\section{Conclusion}

Health is a fundamental human right, and UHC is a key to achieve health for all. Addressing the needs for UHC achievement, it is important to break down the access barriers by removing financial, geographical and cultural barriers in a sustained way that reduce the out of pocket expenditure among Bangladeshi people. Additionally, COVID-19 pandemic focused the necessity of healthy economy by controlling the pandemic effectively with sustainable solution measures. As a lower middle income country, Bangladesh has limited resources in health sectors which needed rapid reforms of resources for achieving UHC by 2032. Hence, by developing the need basis stronger and resilient health infrastructure the country will be able to provide timely response during any health crisis including better protection against future outbreak control with access to needed health care excluding financial burden.

\section{Competing interests}

The authors declare no competing interests. 
medRxiv preprint doi: https://doi.org/10.1101/2020.11.11.20229526; this version posted November 13,2020 . The copyright holder for this preprint (which was not certified by peer review) is the author/funder, who has granted medRxiv a license to display the preprint in It is made available under a CC-BY-NC-ND 4.0 International license .

\section{References}

[1] WHO, "Universal health coverage," World Health Organization, 2020. .

[2] WHO, "Universal health coverage (UHC)," WHO, 2019. .

[3] N. I. Alamgir, N. Naher, A. K. Paul, T. Hossain, and S. M. Ahmed, Building Awareness on Universal Health Coverage: Advancing the Agenda in Bangladesh. 2017.

[4] R. Shahidur, "Universal health coverage in Bangladesh: The challenges," The Financial Express, 2019. .

[5] C. Wang et al., "Immediate psychological responses and associated factors during the initial stage of the 2019 coronavirus disease (COVID-19) epidemic among the general population in China," Int. J. Environ. Res. Public Health, vol. 17, no. 5, p. 1729, Mar. 2020, doi: 10.3390/ijerph17051729.

[6] WHO, "Coronavirus disease (COVID-19) update," World Health Organization, 2020.

[7] A. H. Khan, M. S. Sultana, S. Hossain, M. T. Hasan, H. U. Ahmed, and M. T. Sikder, "The impact of COVID-19 pandemic on mental health \& wellbeing among homequarantined Bangladeshi students: A cross-sectional pilot study," J. Affect. Disord., vol. 277, no. January, pp. 121-128, 2020, doi: 10.1016/j.jad.2020.07.135.

[8] M. Z. Ferdous, M. S. Islam, M. T. Sikder, A. S. M. Mosaddek, J. A. Zegarra-Valdivia, and D. Gozal, "Knowledge, attitude, and practice regarding COVID-19 outbreak in Bangladesh: An online-based cross-sectional study," PLoS One, vol. 15, no. 10, p. e0239254, Oct. 2020, [Online]. Available: https://doi.org/10.1371/journal.pone.0239254.

[9] reliefweb, "Bangladesh: Rapid Assessment Findings on Covid-19 Effects on Urban Health - Bangladesh | ReliefWeb," reliefweb, 2020. .

[10] worldometer, "Bangladesh Coronavirus: 412,647 Cases and 5,983 Deaths Worldometer," worldometer, 2020. .

[11] F. E. Akinleye, G. R. Akinbolaji, and J. O. Olasupo, "Towards universal health 
medRxiv preprint doi: https://doi.org/10.1101/2020.11.11.20229526; this version posted November $13,2020$. The copyright holder for this preprint (which was not certified by peer review) is the author/funder, who has granted medRxiv a license to display the preprint in It is made available under a CC-BY-NC-ND 4.0 International license .

coverage: lessons learnt from the COVID-19 pandemic in Africa," Pan Afr. Med. J., vol. 35, no. December 2019, pp. 2019-2020, 2020, doi:

10.11604/pamj.supp.2020.35.2.24769.

[12] M. E. Kruk and M. Pate, "The Lancet Global Health Commission on High Quality Health Systems 1 year on: progress on a global imperative," Lancet Glob. Heal., vol. 8, no. 1, pp. e30-e32, 2020, doi: 10.1016/S2214-109X(19)30485-1.

[13] K. A. Muhammed, "Crossing the quality chasm_ Nigeria's long walk to universal health coverage - The Center for Policy Impact in Global Health," Cent. Policy Impact Glob. Heal., 2020.

[14] Dhaka Tribune, "Covid-19: Immediate expansion of testing labs to districts needed | Dhaka Tribune," Dhaka Tribune, 2020. .

[15] M. Mohammad, Al-Masum, "Govt now scrambles for testing kits, PPE | The Daily Star," The Daily Star, 2020. .

[16] C. Shahidul, Islam, "China to give Bangladesh testing kits, protective gears," NEWAGE Bangladesh, 2020. .

[17] M. B. Latif, A. Irin, and J. Ferdaus, "Socio-economic and health status of slum dwellers of the Kalyanpur slum in Dhaka city," Bangladesh J. Sci. Res., vol. 29, no. 1, pp. 73-83, Sep. 2016, doi: 10.3329/bjsr.v29i1.29760.

[18] Y. Arias Granada, S. Haque, G. Joseph, and M. Yanez Pagans, "Water and sanitation in Dhaka slums : access, quality, and informality in service provision,” World Bank Policy Res. Work. Pap., no. 8552, 2018, doi: 10.1596/1813-9450-8552.

[19] K. Md, “Coronavirus fear grips Rohingya camps in Bangladesh,” Anadolu Agency, 2020. .

[20] S. Anwar, M. Nasrullah, and M. J. Hosen, "COVID-19 and Bangladesh: Challenges and How to Address Them," Front. Public Heal., vol. 8, no. April, pp. 1-8, 2020, doi: 10.3389/fpubh.2020.00154.

[21] Care Evaluations, "Rapid Needs Assessment COVID-19 impacts on Urban Health in Bangladesh - CARE | Evaluations," Care Evaluations, 2020. . 
medRxiv preprint doi: https://doi.org/10.1101/2020.11.11.20229526; this version posted November 13, 2020. The copyright holder for this preprint (which was not certified by peer review) is the author/funder, who has granted medRxiv a license to display the preprint in It is made available under a CC-BY-NC-ND 4.0 International license .

[22] L. R. Kundu, M. Z. Ferdous, U. S. Islam, and M. Sultana, "Forecasting the spread of COVID-19 pandemic in Bangladesh using ARIMA model," medRxiv, p. 2020.10.22.20217414, Jan. 2020, doi: 10.1101/2020.10.22.20217414.

[23] M. Z. Ferdous, L. R. Kundu, M. Sultana, and S. J. Jafrin, “Original Article Regional differences in COVID-19 attack and case fatality rates in the first quarter of 2020 : a comparative study," IMC J. Med. Sci., vol. 14, no. 2, pp. 3-10, 2020. 